\title{
PENGARUH SISTEM INFORMASI AKUNTANSI DAN INTEGRITAS TERHADAP KINERJA KARYAWAN PADA RSUD SMC TASIKMALAYA
}

\author{
Cepi Juniar Prayoga ${ }^{1 *}$, Fithri Sri Mulyani ${ }^{2}$, Susi Mulyati ${ }^{2}$ \\ ${ }^{1}$ Universitas Garut, Jl. Raya Samarang No. 52A Tarogong Kidul, Garut \\ ${ }^{2}$ STIE Cipasung Tasikmalaya, Jl Muktamar NU No 29 Singaparna, Tasikmalaya \\ "Korespondensi: cepijuniar@uniga.ac.id
}

\begin{abstract}
This study aims to examine the effect of accounting information systems and integrity on employee performance at SMC Tasikmalaya Hospital. The populations in this study were employees of the SMC Tasikmalaya Hospital as many as 491 people. The sampling technique used stratified random sampling. The data used is primary data obtained directly from respondents using a questionnaire. The data analysis technique uses multiple linear regressions. The results of this study indicate that the accounting information system partially affects employee performance. Integrity partially affects employee performance. Meanwhile, simultaneously accounting information system and integrity affect employee performance.
\end{abstract}

Keywords: Accounting Information System, Integrity, Employee Performance

\begin{abstract}
ABSTRAK
Penelitian ini mempunyai tujuan untuk menguji pengaruh sistem informasi akuntansi dan integritas terhadap kinerja karyawan RS SMC Tasikmalaya. Populasi dalam penelitian ini adalah karyawan pelaksana RS SMC Tasikmalaya sebanyak 491 orang.Teknik pengambilan sampel menggunakan stratified random sampling.Data yang digunakan adalah data primer yang diperoleh langsung dari responden dengan menggunakan kuiesioner.Teknik analisis data menggunakan metode regresi linier berganda.Hasil penelitian ini menunjukkan bahwa sistem informasi akutansi secara parsial berpengaruh terhadap kinerja karyawan.Integritas secara parsial berpengaruh terhadap kinerja karyawan. Sedangkan secara simultan sistem informasi akuntansi dan integritas berpengaruh terhadap kinerja karyawan.
\end{abstract}

Kata kunci: Sistem Informasi Akuntansi, Integritas, Kinerja Karyawan 


\section{PENDAHULUAN}

Rumah Sakit merupakan institusi pelayanan kesehatan yang menyelenggarakan pelayanan kesehatan perorangan secara paripurna dengan menyediakan pelayanan rawat inap, rawat jalan, dan gawat darurat (UU No. 44 tahun 2009). Rumah sakit mempunyai tugas melaksanakan upaya kesehatan secara berdayaguna dan berhasil guna dengan menggutamakan upaya kuratif dan rehabilitatif yang dilaksanakan secara serasi dan terpadu dengan upaya promotif dan preventif serta melaksanakan upaya rujukan. Oleh karena itu, rumah sakit dituntut untuk dapat memberikan pelayanan kesehatan yang bermutu, aman dan profesional sesuai dengan perkembangan ilmu pengetahuan teknologi (IPTEK) kesehatan serta kebutuhan dan tuntutan masyarakat.

Pelayanan kesehatan yang baik dapat terwujud dengan meningkatkan kualitas sumber daya manusia melalui kinerja. Menurut Mangkunegara (2014) kinerja diartikan sebagai kualitas dan kuantitas dari hasil kerja yang telah dicapai oleh pegawai dalam melaksanakan tugasnya sesuai dengan tanggung jawabnya. Kinerja karyawan di rumah sakit dapat memberikan efek penting terhdap kualitas pelayanan di rumah sakit. Sehingga karyawan diharapkan tumbuh kesadaran, kemauan dan mampu mengidentifikasi kualitas kinerja masing-masing, untuk dimonitor, diperbaiki serta ditingkatkan secara terus-menerus (Tjahyono, 2016).

Peningkatan kinerja karyawan di rumah sakit sangat penting dan sudah merupakan tuntutan karena adanya berbagai aspek yang berhubungan dengan upaya peningkatan pelayanan kesehatan. Termasuk kemampuan apakah dari segi pendidikan, pelatihan, dan lama kerja, juga motivasi kerja. Upaya mencapai kinerja yang baik, maka upaya tersebut harus dilaksanakan secara terpadu dan multi disiplin sera melibatkan seluruh tenaga kesehatan yang terkait (Innong, 2010).

Adanya evaluasi dari pengambil keputusan melalui data dari sistem informasi akuntansi sebagai pengendalian internal terhadap kinerja rumah sakit dan kinerja karyawan. Sistem Informasi Akuntansi adalah suatu kumpulan sumber daya manusia dan modal dalam suatu organisasi yang bertugas dalam menyiapkan informasi keuangan dan informasi yang diperoleh dari pengumpulan pengolahan transaksi. Pengoperasian dalam Sistem Informasi Akuntansi tidak terlepas dari adanya persiapan data sebagai komponen input, memberikan Informasi dari data yang akurat serta memiliki instrument pengendalian (Baridwan, 2013). Pemanfaatan teknologi Sistem Informasi Akuntansi tersebut terjadi efisien kerja, meminimalisasi kesalahan dan kecepatan dalam pelaporan agar dapat membuat keputusan secara cepat dan akurat. Karyawan memahami secara betul implementasi dari sistem informasi akuntansi, karena sistem ini akan mempermudah dan mempercepat proses kerja sehingga karyawan dapat menunjukkan kinerja yang maksimal bagi rumah sakit.

Selain faktor SIA, terdapat faktor lainnya yaitu integritas. Integritas merupakan kualitas yang menjadikan timbulnya kepercayaan masyarakat dan tatanan nilai tertinggi bagi anggota profesi dalam menguji semua keputusannya (Bernard, (2017). Seorang pegawai harus bersikap jujur, komitmen dan konsisten dalam melaksanakan tugasnya. integritas juga merupakan komponen penting dalam mempengaruhi kinerja, karena integritas berkaitan erat dengan komitmen. Orang yang gagal dalam berkomitmen menunjukkan lemahnya integritas dalam dirinya. Integritas adalah suatu pola pikir dan karakter yang sesuai dengan norma dan peraturan yang berlaku. Integritas diri berkaitan dengan sikap selalu mengedepankan tanggung jawab, kepercayaan, dan kesetiaan terhadap janji (Prayitno, 2013).

Menurut data pegawai RS SMC (2021) diperoleh informasi bahwa jumlah karyawan sebanyak 677 orang yang terdiri dari Pegawai Negeri Sipil 186 orang dan Pegawai Kontrak Blud: 491 Orang. RS SMC Tasikmalaya telah menggunakan SIA, namun sumber daya manusia dan sarana pendukung lain dari Sistem Informasi 
Akuntansi belum dapat efektif dan digunakan secara optimal. Indikator kinerja pelayanan yang meliputi tingkat pemanfaatan fasilitas atau sarana RS, tingkat efisiensi dan mutu pelayanan di RSUD Singaparna Medika Citrautama Kabupaten Tasikmalaya Tahun 2019. Dari informasi yang diperoleh Indikator BOR mencapai angka yaitu 60\%. Kenyataan di RS SMC Tasikmalaya, kinerja karyawan masih terkesan belum sepenuhnya tercapai. Hal ini terlihat dari beberapa fenomena seperti kuantitas dan kualitas pegawai masih rendah, kurangnya pengetahuan dan kemampuan pegawai dalam bekerja, kurangnya ketepatan waktu dalam menyelesaikan pekerjaan sesuai dengan keinginan pimpinan, kerjasama antara rekan kerja masih kurang, fasilitas penunjang kerja masih kurang, dan pengawasan dan evaluasi dari atasan terhadap bawahan belum terlaksana secara optimal.

Integritas karyawan didapatkan masih banyak karyawan yang bermasalah dalam bekerja. Bentuk dari masalah tersebut diantaranta adalah kurangnya kerja sama antar pegawai, belum dapat konsisten dalam pembuatan laporan, dalam hal penyusunan dokumen juga terdapat karyawan yang bekerja kurang rapi dan kurang teliti, sehingga banyak ditemukan kesalahan dalam penulisan, dan pelaporan halaman tidak terhubung dengan halaman lainnya dan banyak kesalahan-kesalahan lain. Hal ini menunjukkan bahwa integritas karyawan masih belum sesuai dengan yang di harapkan.

Masalah lain yang ditemukan adalah banyak karyawan yang boros dalam penggunaan APD seperti masker atau sarung tangan yang sekali pakai, padahal belum digunakan. Kurang memiliki tanggung jawab dalam menjaga atau merawat barang atau inventaris rumah sakit. Lebih fokus dengan orientasi pekerjaan sendiri tanpa memperhatikan kebutuhan teman sejawat atau pengunjung rumah sakit. Hal ini dikarenakan oleh beberapa factor, seperti kurangnya tanggung jawab pegawai yang berkaitan dengan penegakkan nilai etika, pegawai. Sementara itu, kecakapan profesional berupa kemampuan untuk melaksanakan pekerjaan secara efisien juga dapat menyebabkan tidak terwujudnya integritas dalam diri seorang pegawai.

Sehubungan dengan fenomena tersebut telah dilakukan penelitian mengenai kinerja karyawan oleh Wijayanti (2013) dalam penelitiannya menjelaskan bahwa terdapat pengaruh positif dan signifikan antara teknologi sistem informasi akuntansi terhadap kinerja individual pada pegawai. Begitupun dengan penelitian Yolanda (2019) dalam penelitiannya menemukan bahwa semua sub variabel integritas (terdiri dari kejujuran, komitmen, dan konsistensi) berpengaruh signifikan terhadap kinerja. Begitupun dengan penelitian (Sugiyono, 2017) yang menemukan bahwa integritas berpengaruh signifikan terhadap kinerja pegawai, hal ini menunjukanan bahwa semakin tinggi integritas yang dimiliki pegawai terhadap organisasi atau tempat dia bekerja maka kinerja yang ditunjukkan oleh pegawai tersebut juga akan mengalami peningkatan yang cukup signifikan, secara tidak langsung kinerja organisasi perangkat daerah (OPD) juga akan mengalami peningkatan.

Penelitian ini merujuk pada fenomena dan penelitian terdahulu yang membedakan terletak pada objek penelitian dan penambahan variable integritas yang lebih ditekan kan ke prilaku pegawai. Berdasarkan hal tersebut, maka dapat dirumuskan hipotesisnya sebagai berikut:

$\mathrm{H}_{1}$ : Sistem Informasi Akuntansi berpengaruh terhadap kinerja karyawan di RSUD SMC Tasikmalaya.

$\mathrm{H}_{2}$ : Integritas karyawan berpengaruh terhadap kinerja karyawan di RSUD SMC Tasikmalaya.

$\mathrm{H}_{3}$ : Sistem Informasi Akuntansi dan integritas berpengaruh terhadap kinerja karyawan di RSUD SMC Tasikmalaya 


\section{METODE PENELITIAN}

Dalam penilitian ini, variabel Independennya terdiri dari SIA(X1) dan Integritas (X). Sedangkan variabel dependennya terdiri dari variabel kinerja perusahaan (Y).

\section{Tabel 1. Definisi Operasional}

\begin{tabular}{|c|c|c|c|}
\hline Variabel & Definisi & Indikator & Skala \\
\hline SIA & $\begin{array}{l}\text { Sistem yang dirancang untuk } \\
\text { mengolah data mengenai akuntansi } \\
\text { suatu perusahaan atau organisasi } \\
\text { dan diharapkan menghasilkan } \\
\text { output yang relevan sebagai } \\
\text { pengambilan keputusan. }\end{array}$ & $\begin{array}{ll}\text { - } & \text { Persiapan data } \\
\text { - } & \text { Informasi dari } \\
\text { data } \\
\text { - } \\
\text { Tersedia } \\
\text { instrument } \\
\text { pengendalian }\end{array}$ & Interval \\
\hline Integritas & $\begin{array}{l}\text { Sebuah loyalitas kepada prinsip } \\
\text { dan nilai moral universal, dan } \\
\text { bukan kepada prinsip yang } \\
\text { dipegang pada taraf individu, } \\
\text { organisasi, ataupun masyarakat. }\end{array}$ & $\begin{array}{ll}- & \text { Kejujuran } \\
\text { - } & \text { Komitmen } \\
- & \text { Konsisten }\end{array}$ & Interval \\
\hline $\begin{array}{l}\text { Kinerja } \\
\text { Karyawan }\end{array}$ & $\begin{array}{l}\text { hasil yang dicapai atau prestasi } \\
\text { yang dicapai karyawan dalam } \\
\text { melaksanakan suatu pekerjaan } \\
\text { dalam suatu organisasi. }\end{array}$ & $\begin{array}{ll}\text { - } & \text { Kualitas (Quality) } \\
\text { - } & \text { Kuantitas } \\
& \text { (Quantitas) } \\
\text { - } & \text { Ketetapan waktu } \\
\text { - } & \text { (Timeliness) } \\
\text { Efektifitas biaya } \\
\text { (cost effectiviness) } \\
\text { - } & \text { Kebutuhan } \\
\text { supervisi } \\
\text { - } & \text { hubungan } \\
\text { personal } \\
\text { (Impersonal } \\
\text { Impact) } \\
\end{array}$ & Interval \\
\hline
\end{tabular}

Populasi dalam penelitian ini adalah karyawan pelaksana RS SMC Tasikmalaya sebanyak 491 orang. Teknik pengambilan sampel menggunakan stratidied random sampling, dengan menggunakan rumus slovin sebagai berikut

$$
n=\frac{N}{1+N\left(d^{2}\right)}
$$

Keterangan :

$\mathrm{n}=$ Jumlah sampel

$\mathrm{N}=$ Jumlah Populasi

$\mathrm{d}=$ Tingkat kepercayaan 0,05 (5\%)

$$
\begin{aligned}
& n=\frac{491}{1+491\left(0.05^{2}\right)} \\
& n=\frac{491}{1+491(0.0025)}
\end{aligned}
$$

$n=\frac{491}{1+1,2275}$

$$
\begin{aligned}
& n=\frac{491}{2,2275} \\
& \mathrm{n}=220,42 \text { dibulatkan menjadi } 220 \text { orang }
\end{aligned}
$$


Analisis data yang digunakan dalam penelitian ini adalah regresi linear berganda, uji validitas dan reliabilitas serta uji asumsi klasik. Untuk menguji analisi dalam penelitian ini dilakukan membuat persamaan regresi dengan rumus sebagai berikut: $\mathrm{Y}=\mathrm{a}+\mathrm{b}_{1} \mathrm{X}_{1}+\mathrm{b}_{2} \mathrm{X}_{2}+\varepsilon$

Dimana:

Y : Kinerja Karyawan

X1: Sistem Informasi Akuntansi

X2: Integritas

a : Nilai konstanta harga $\mathrm{Y}$ jika $\mathrm{X}=0$

$\mathrm{b}$ : Nilai arah sebagai penentu ramalan yang menunjukan nilai peningkatan atau penurunan variabel $Y$.

$\varepsilon$ : Error term

\section{HASIL DAN PEMBAHASAN}

\section{Uji Kualitas Instrumen}

\section{Uji Validitas}

Hasil uji validitas dari hasil penyebaran kuesioner mengenai variabel Sistem Informasi Akuntansi adalah sebagai berikut:

Tabel 2. Uji validitas variabel Sistem Informasi Akuntansi Dan Intergitas

\begin{tabular}{|c|c|c|c|c|c|}
\hline & \multirow{2}{*}{$\begin{array}{l}\text { Corrected } \\
\text { Item-Total } \\
\text { Correlation }\end{array}$} & \multirow{2}{*}{$\begin{array}{c}\text { R tabel } \\
(n=20,: \\
0,444\end{array}$} & \multirow{2}{*}{\multicolumn{2}{|c|}{$\begin{array}{l}\text { Corrected } \\
\text { Item-Total } \\
\text { Correlation }\end{array}$}} & \multirow{2}{*}{$\begin{array}{c}\mathrm{R} \text { tabel } \\
(\mathrm{n}=20,: 0,444\end{array}$} \\
\hline & & & & & \\
\hline s1 & 0.721 & Valid & i1 & 0.847 & Valid \\
\hline $\mathrm{s} 2$ & 0.649 & Valid & $\mathrm{i} 2$ & 0.702 & Valid \\
\hline s3 & 0.541 & Valid & i3 & 0.595 & Valid \\
\hline s4 & 0.726 & Valid & i4 & 0.587 & Valid \\
\hline s5 & 0.573 & Valid & i5 & 0.598 & Valid \\
\hline s6 & 0.539 & Valid & i6 & 0.571 & Valid \\
\hline s7 & 0.733 & Valid & i7 & 0.692 & Valid \\
\hline s8 & 0.713 & Valid & i8 & 0.653 & Valid \\
\hline s9 & 0.692 & Valid & i9 & 0.603 & Valid \\
\hline $\mathrm{s} 10$ & 0.572 & Valid & $\mathrm{i} 10$ & 0.647 & Valid \\
\hline
\end{tabular}

Hasil uji validitas menunjukan bahwa nilai Corrected Item-Total Correlation (r hitung) tiap item pernyataan yang diperoleh nilai $r$ hitung lebih besar dari nilai $t$ tabel $(\mathrm{df}=\mathrm{n}-2=18: \alpha=0,05=0,468)$. Hasil uji validitas dari hasil penyebaran kuesioner mengenai variabel kinerja kerja adalah sebagai berikut: 
Tabel 3. Uji validitas variabel kinerja

\begin{tabular}{lrc}
\hline & $\begin{array}{c}\text { Corrected } \\
\text { Item-Total } \\
\text { Correlation }\end{array}$ & $\begin{array}{c}\text { R tabel } \\
\text { (n-2: } \mathbf{0 , 4 6 8}\end{array}$ \\
\hline k1 & .817 & Valid \\
k2 & .759 & Valid \\
k3 & .732 & Valid \\
k4 & .674 & Valid \\
k5 & .497 & Valid \\
k6 & .804 & Valid \\
k7 & .710 & Valid \\
k8 & .807 & Valid \\
k9 & .777 & Valid \\
k10 & .752 & Valid \\
k11 & .559 & Valid \\
k12 & .787 & Valid \\
\hline
\end{tabular}

Dengan demikian data kuesioner yang dibagikan kepada responden untuk variabel Sistem Informasi Akuntansi, Integritas, dan kinerja dapat dinyatakan valid dan layak sebagai alat ukur dalam analisis data selanjutnya.

\section{Uji Reliabilitas}

Perhitungan uji reliabilitas dari pernyataan variabel Persepsi SIA , integritas dn kinerja hasilnya terlihat pada tabel berikut:

Tabel 4. Uji reliabilitas variabel Sistem Informasi Akuntansi, integritas dan kinerja

\begin{tabular}{lc}
\hline \multicolumn{1}{c}{ Variabel } & Cronbach's Alpha \\
\hline Sistem Informasi Akuntansi & 0.896 \\
Integritas & 0.900 \\
Kinerja & 0.939 \\
\hline
\end{tabular}

Tabel diatas menunjukkan nilai alpha cronbach untuk variabel Sistem Informasi Akuntansi, Integritas kerja dan kinerja memiliki nilai lebih dari 0,6 sehingga pertanyaan ketiga variabel tersebut dinyatakan sangat reliabel.

\section{Uji Asumsi Klasik}

\section{Uji Normalitas}

Tabel 5. Uji normalitas variabel Sistem Informasi Akuntansi, integritas dan kinerja OneSample Kolmogorov-Smirnov Test

\begin{tabular}{llrrr}
\hline & & $\begin{array}{c}\text { Sistem Informasi } \\
\text { Akuntansi }\end{array}$ & \multicolumn{2}{c}{ Kinerja } \\
& & 220 & 220 & \multicolumn{2}{c}{ Karyawan } \\
\hline $\mathrm{N}$ & & 42.45 & 42.09 & 50.55 \\
Normal Parameters & Mean & 2.671 & 2.535 & 3.216 \\
& Std. Deviation & .090 & .091 & .089 \\
Most Extreme & Absolute & .090 & .091 & .089 \\
Differences & Positive & -.069 & -.082 & -.070 \\
& Negative & 1.339 & 1.348 & 1.324 \\
Kolmogorov-Smirnov Z & & .055 & .053 & .060 \\
Asymp. Sig. (2-tailed) & & & & \\
\hline
\end{tabular}


Data pada tabel diatas menunjukkan bahwa hasil uji ormalitas untuk sampel 220 menggunakan uji kolomogrov smirnov, pada kolom sig didapatkan $p$ value $>0,05$ sehingga seluruh pertanyaan pada tiap variabel distribusi normal.

\section{Uji Multikolinearitas}

Tabel 6. Uji Multikoloniearitas

\begin{tabular}{llrl}
\hline & & \multicolumn{2}{c}{ Collinearity Statistics } \\
Model & & Tolerance & VIF \\
\hline 1 & (Constant) & & \\
& $\begin{array}{l}\text { Sistem Informasi } \\
\text { Akuntansi }\end{array}$ & .694 & 1.441 \\
& Integritas & & \\
\end{tabular}

Nilai Tolerance mendekati angka 1 dengan nilai masing-masing untuk Sistem Informasi Akuntansi sebesar 0.694, integritas sebesar 0,694. Hal ini menunjukan bahwa tidak terjadi multikolinearitas pada model regresi yang digunakan.

\section{Uji Heteroskedastisitas}

Korelasi koefesiensi variabel Sistem Informasi Akuntansi dengan nilai sebesar 0.631, Integritas sebesar 0,849 $(>0.05(\alpha=5 \%)$, dengan demikian variabel Sistem Informasi Akuntansi, dan integritas dengan kinerja tidak terhadi heteroskedastisitas. Untuk lebih jelasnya dapat dilihat pada tabel berikut:

Tabel 7. Uji Heteroskedastisitas

\begin{tabular}{llll} 
& \multicolumn{1}{c}{ Model } & $\mathrm{t}$ & \multicolumn{2}{c}{ Sig. } \\
\hline 1 & (Constant) & .570 & .569 \\
& Sistem Informasi & .482 & .631 \\
Akuntansi & & \\
& Integritas & -.191 & .849 \\
\hline
\end{tabular}

a. Dependent Variable: Abs_RES

\section{Analisis Regresi Linear Berganda}

Berdasarkan hasil perhitungan SPSS 17. for windows diperoleh model persamaan regresi:

Tabel 8. Analisis Regresi Linear Berganda

\begin{tabular}{|c|c|c|c|c|}
\hline & \multirow{2}{*}{ Model } & \multicolumn{2}{|c|}{$\begin{array}{l}\text { Unstandardized } \\
\text { Coefficients }\end{array}$} & \multirow{2}{*}{$\begin{array}{c}\text { Standardized } \\
\text { Coefficients } \\
\text { Beta }\end{array}$} \\
\hline & & $\mathrm{B}$ & Std. Error & \\
\hline \multirow[t]{3}{*}{1} & (Constant) & 3.726 & 2.423 & \\
\hline & $\begin{array}{l}\text { Sistem Informasi } \\
\text { Akuntansi }\end{array}$ & .330 & .059 & .274 \\
\hline & Integritas & .779 & .062 & .614 \\
\hline
\end{tabular}

Berdasarkan persamaan diatas dapat diartikan bahwa:

a. Nilai konstanta negatif dengan nilai sebesar 3,726. menunjukkan apabila faktor Sistem Informasi Akuntansi, integritas dianggap nol (0) atau tidak ada, maka skor kinerja karyawan sebesar 3.726

b. Koefesiensi faktor $\mathrm{X}_{1}$ (Sistem Informasi Akuntansi) 
Pada kolom Unstandardized Coefficients baris variabel Sistem Informasi Akuntansi diperoleh nilai koefesien positif sebesar 0,330. Nilai tersebut dapat diartikan apabila nilai Sistem Informasi Akuntansi naik sebesar 1 poin, sedangkan variabel integritas $\left(X_{2}\right)$ tetap konstan, maka akan faktor disiplin meningkatkan nilai kinerja pegawai sebesar 0,330 poin.

c. Koefesiensi faktor $\mathrm{X}_{2}$ (Integritas)

d. Pada kolom Unstandardized Coefficients baris variabel integritas diperoleh nilai koefesien positif sebesar 0,779. Nilai tersebut dapat diartikan apabila nilai integritas naik sebesar 1 poin, sedangkan variabel Sistem Informasi Akuntansi $\left(\mathrm{X}_{1}\right)$ tetap konstan, maka faktor integritas meningkatkan nilai kinerja pegawai sebesar 0,779 poin.

\section{Uji Hipotesis}

\section{Uji t (parsial)}

Uji t menunjukkan seberapa jauh pengaruh variabel indevenden secara parsial terhadap variabel dependen. Untuk menguji hipotesis t dengan kriteria pengambilan keputusan dengan membandingkan nilai signifikansi $\alpha \geq 0,05$ Berdasarkan hasil uji t dapat diketahui secara individual (parsial) variabel Sistem Informasi Akuntansi dan integritas berpangaruh terhadap kinerja ( $p$ value $<0,05$ ). Untuk lebih jelasnya mengenai hasil uji t dapat dilihat pada tabel berikut

Tabel 9. Analisis Uji Parsial (Uji t)

\begin{tabular}{|c|c|c|c|c|c|c|}
\hline & \multirow[t]{2}{*}{ Model } & \multicolumn{2}{|c|}{$\begin{array}{l}\text { Unstandardized } \\
\text { Coefficients }\end{array}$} & \multirow{2}{*}{$\begin{array}{c}\text { Standardized } \\
\text { Coefficients } \\
\text { Beta }\end{array}$} & \multirow[t]{2}{*}{$\mathrm{T}$} & \multirow[t]{2}{*}{ Sig. } \\
\hline & & $\mathrm{B}$ & Std. Error & & & \\
\hline \multirow[t]{3}{*}{1} & (Constant) & 3.726 & 2.423 & & 1.538 & .126 \\
\hline & $\begin{array}{l}\text { Sistem Informasi } \\
\text { Akuntansi }\end{array}$ & .330 & .059 & .274 & 5.606 & .000 \\
\hline & Integritas & .779 & .062 & .614 & 12.549 & .000 \\
\hline
\end{tabular}

\section{Uji F (simultan)}

Pengujian secara simultan (bersama-sama) dilakukan dengan uji $F$, untuk menguji hipotesis ini digunakan statistik $\mathrm{F}$ dengan kriteria pengambilan keputusan dengan tingkat kepercayaan 0,05. Dari hasil uji F didapat nilai probabilitas (sign) $0,000$ pada taraf signifikansi 5\% ( $<0,05)$. Hasil tersebut membuktikan bahwa variabel bebas (Sistem Informasi Akuntansi, integritas) secara bersama-sama (simultan) berpengaruh signifikansi terhadap kinerja karyawan

Tabel 10. Analisis Uji Simultan (Uji F) ANOVA

\begin{tabular}{|c|c|c|c|c|c|c|}
\hline & Model & $\begin{array}{l}\text { Sum of } \\
\text { Squares }\end{array}$ & df & Mean Square & $\mathrm{F}$ & Sig. \\
\hline \multirow[t]{3}{*}{1} & Regression & 1447.392 & 2 & 723.696 & 192.182 & $.000^{\mathrm{a}}$ \\
\hline & Residual & 817.154 & 217 & 3.766 & & \\
\hline & Total & 2264.545 & 219 & & & \\
\hline
\end{tabular}

a. Predictors: (Constant), Sistem Informasi Akuntansi, Integritas

b. Dependent Variable: Kinerja Karyawan 
Tabel 11. Tabel uji koefisiensi korelasi (R) Model Summary

\begin{tabular}{lrrrrr}
\hline Model & R & R Square & $\begin{array}{c}\text { Adjusted R } \\
\text { Square }\end{array}$ & $\begin{array}{l}\text { Std. Error of } \\
\text { the Estimate }\end{array}$ & $\begin{array}{l}\text { Durbin- } \\
\text { Watson }\end{array}$ \\
\hline 1 & $.799^{\mathrm{a}}$ & .639 & .636 & 1.941 & 2.053 \\
\hline
\end{tabular}

a. Predictors: (Constant), Sistem Informasi Akuntansi, Integritas

b. Dependent Variable: Kinerja Karyawan

Uji Koefisien Determinasi $\left(\mathrm{R}^{2}\right)$ pada penelitian ini didapatkan persamaan data pada tabel diatas dapat dijelaskan pada rumus berikut:

$\mathrm{Kd}=\mathrm{r}^{2} \mathrm{x} 100 \%$

Keterangan:

$\mathrm{Kd} \quad=$ Koefisien determinasi

$\mathrm{r} \quad=$ koefesiensi korelasi

Sehingga diperoleh perhitungan $\mathrm{Kd}=0.799^{2} \times 100 \%=63,9 \%$. Melalui tabel summary diperoleh nilai R Square atau koefisien determinasi (KD) yang menunjukkan seberapa bagus model regresi yang dibentuk oleh interaksi variabel bebas dan variabel terikat. Nilai KD yang diperoleh adalah 0,639 yang dapat ditafsirkan bahwa variabel Sistem Informasi Akuntansi dan Integritas mempengaruhi 63,9\% terhadap kinerja karyawan sehingga sisanya yaitu 36.1\% dipengruhi oleh faktor lain yang tidak diteliti dalam penelitian ini.

\section{Pengaruh Sistem Informasi Akuntansi kerja terhadap kinerja karyawan.}

Sistem Informasi Akuntansi berpengaruh terhadap kinerja karyawan RS SMC Tasikmalaya. Hasil penelitian tersebut sejalan dengan penelitian Transetio (2019) yang menemukan bahwa sistem informasi akuntansi berpengaruh posistif terhadap kinerja karyawan. Hal tersebut dapat didukung oleh beberapa karyawan sudah mampu mengoperasikan sistem informasi akuntansi yang sudah ada. Sejalan dengan pernyataan tersebut penelitian lainnya yang dilakukan oleh Nayaka (2019) yang menunjukkan bahwa sistem informasi akuntansi yang telah diterapkan telah mampu meningkatkan kinerja karyawan.

\section{Pengaruh Integritas terhadap kinerja karyawan.}

Integritas berpengaruh terhadap kinerja Karyawan di RS SMC Tasikmalaya. Hal ini menunjukkan bahwa semakin tinggi Integritas akan berdampak pada semakin tinggi tingkat kinerja karyawan. Hasil penelitian yang dilakukan oleh Karapinar (2015) dan (Awaludin et al., 2016) juga menunjukkan bahwa integritas berpengaruh positif dan signifikan pada kinerja pegawai.

\section{Pengaruh Sistem Informasi Akuntansi kerja dan Integritas terhadap kinerja karyawan}

Sistem Informasi Akuntansi, integritas sama-sama berpengaruh pada kinerja karyawan, (Chan, 2011). Sistem informasi akuntansi memproses berbagai transaksi keuangan dan transaksi non keuangan yang secara langsung mempengaruhi pemrosesan transaksi keuangan di rumah sakit. Sehingga dengan adana SIA, akan menjadikan dasar bagi kebijakan dalam mengambil keputusan yang akan mepengaruhi pada sikap dan integritas dari karyawan.

Hasil penelitian tersebut sejalan dengan penelitian Transetio (2019) yang menemukan bahwa sistem informasi akuntansi berpengaruh posistif terhadap kinerja karyawan dan penelitian yang dilakukan oleh Karapinar (2015) dan (Awaludin et al., 2016) menunjukkan bahwa integritas berpengaruh positif dan signifikan pada kinerja pegawai. 


\section{SIMPULAN}

Sistem Informasi Akuntansi berpengaruh terhadap kinerja karyawan pada RSUD SMC Tasikmalaya. Hal ini menunjukkan bahwa semakin baik teknologi sistem informasi akuntansi maka semakin baik pula kinerja individual pegawai. Integritas karyawan berpengaruh terhadap kinerja karyawan pada RSUD SMC Tasikmalaya. Hal ini menunjukkan bahwa semakin tinggi Integritas akan berdampak pada semakin tinggi tingkat kinerja karyawan. Sistem Informasi Akuntansi dan integritas berpengaruh terhadap kinerja karyawan pada RSUD SMC Tasikmalaya. Hal ini menunjukkan bahwa semakin tinggi Sistem Informasi Akuntansi dan integritas akan berdampak pada semakin tinggi Sistem Informasi Akuntansi dan integritas. Hal ini menujukan bahwa Sistem informasi akuntansi memproses berbagai transaksi sampai menjadi dasar bagi kebijakan dalam mengambil keputusan dengan berlandaskan sikap dan integritas dari karyawan. Penelitian selanjutnya diharapkan tidak hanya sistem informasi akuntansi dan integritas saja tetapi menambahkan faktor lain yang mempengaruhi kinerja

\section{DAFTAR RUJUKAN}

Arikunto, (2010). Prosedur Penelitian Edisi Revisi Ke VI , Rineka Cipta. Jakarta

Awaluddin, L., Adam. L. O. B., dan Maharni, S. W. (2016). The Effect of Job Satisfaction, Integrity and Motivation on Performance, The International Journal of Engineering and Science, 5, 47-52.

Azhar Susanto (2013). Sistem Informasi Akuntansi, -Struktur-Pengendalian Resiko Pengembangan, Edisi Perdana, Lingga Jaya, Bandung

Baridwan, (2013). Sistem Informasi Akuntansi, Yogyakarta. BPFE

Bernadin, (2017). Resourcess Management, Second Edition, MGIH, Boston.

Bernard, (2017) Perilaku Organisasi. Jakarta: Pustaka Raya.

Cushway B, (2016). Human Resouces Manajement, PT. Elex Media Komputindo, Jakarta.

Development Dimensions Internasional (DID). Whitepaper-Driving employee engagement,diunduh dari www.ddiworld.com pada 16 Januari 2021

Gibson, (2016). Perilaku-Struktur-Proses, Jilid II Edisi Kedelapan, Adiami N (Alih Bahasa), Bina Rupa Aksara, Jakarta.

Handoko, (2015). Manajemen Personalia dan Sumber Daya Manusia. Edisi Revisi. BPFE, Yogyakarta.

Hopwood, (2011). Accounting Information System. Yogyakarta: ANDI

Indrayati, (2014). Sistem Informasi Akuntansi (Teori dan Konsep Desain SIA,. Malang: Aditya Media Publishing.

Innong, (2010). Gambaran Kinerja tenaga kesehatan di Puskesmas Maritengngae Kabupaten Sidrap.(Skripsi) Sekolah Tinggi Ilmu kesehatan Baramuli. 
Kemenkes RI, 2010. No.340 atau Menkes atau PER atau III atau 2010 tentang Klasifikasi Rumah Sakit

Kuncoro, (2017). Regulasi Kesehatan Di Indonesia, Andi Yogyakarta.

Luthans, (2012). Organizational Bihavior, Singapore: McGraw Hill Book.

Ma'ruf (2011). Manajemen dan Evaluasi Kinerja Karyawan. Aswaja Pressindo : Yogyakarta

Mangkunegara (2014). Evaluasi Kinerja SDM. Bandung: Refika Aditama

Mardi (2014). Sistem Informasi Akuntansi. Bogor: Ghalia Indonesia

Notoatmodjo, (2010). Ilmu Perilaku dan Pendidikan Kesehatan. Rhineka Cipta. Jakarta.

Nur Nasution, (2015). Manajemen Mutu Terpadu Edisi Kedua, Ghalia Indonesia

Prayitno (2013). Dasar - dasar Bimbingan dan Konseling Edisi revisi. Jakarta : Rineka Cipta.

Putra, (2016). Analisis Faktor-Faktor Yang Mempengaruhi Kinerja Sistem Informasi Akuntansi Pada Lembaga Perkreditan Desa (Lpd) Di Kecamatan Susut. eJournal S1 Ak Universitas Pendidikan Ganesha Volume: 2 No. 1.

Sugiyono (2017), Metode Penelitian Kuantitatif dan Kualitatif. Alfabeta.Bandung

Surya Nayaka A.A Bagus, Suardikha IMS. 2019. Kepuasan Kerja dan Integritas sebagai Pemoderasi Pengaruh Penerapan Sistem Informasi Akuntansi pada Kinerja Karyawan. E-Jurnal Vol.26(1)

Tjahyono, (2016). pengembangan Instrumen Pengembangan Manajemen kinerja (PMK) seluruh tenaga Klinik puskesmas, pusat manajemen pelayanan kesehatan FK UGM bekerja sama dengan WHO

Undang-Undang Nomor 44 Tahun 2009 Tentang Rumah sakit

Wijayanti (2013) . Sumber Daya Manusia, Kreativitas, Inovasi: Pengetahuan Sebagai Sumber Keunggulan Kompetitif Berkesinambungan. Fokus Ekonomi. Vol.2, No.2, 123-135

Wijono, (2010). Manajemen Mutu Pelayanan Kesehatan Vol 1, Airlangga University Pres

Yolanda (2019) . Pengaruh Integritas Terhadap Kinerja Pegawai Negeri Sipil (PNS) di Lingkungan Organisasi Perangkat Daerah (OPD) Dinas Kota Padang. Vol. 3, No. 1, Januari. 2020. ISSN 2622-1748. DOI: http: atau atau dx.doi.org atau

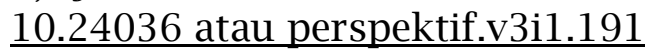

Zahra (2011) Pengaruh Integritas, Kompetensi dan Loyalitas Kepemimpinan terhadap Kepercayaan Para Bawahan di SBU Perkapalan PT. Pusri Palembang. Jurnal Ilmiah Orasi Bisnis. ISSN: 2085-1375. Edisi Ke-VI. Staf Pengajar Jurusan Administrasi Niaga. Politeknik Negeri Sriwijaya 